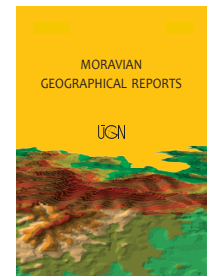

MORAVIAN GEOGRAPHICAL REPORTS

\title{
Sustainable biofuel: A question of scale and aims
}

\author{
Margherita CIERVO a, Serge SCHMITZ ${ }^{\text {** }}$
}

\begin{abstract}
Bio-energy (like other renewable energy sources) is proposed as a solution for climate change and other energy-related and economic issues. The predominant production model, however, which is based on firstgeneration biofuels developed on a global scale, creates ecological impacts throughout the production chain, resulting in a sustainability paradox, as well as social unrest and territorial conflict. Therefore, attention here is focussed on agro-energy and second-generation biofuels, investigating the structural differences, the advantages, the potential problems and the possible solutions of some local biofuel initiatives in North Western Europe. Finally, we propose a regional agrarian model to avoid the impacts and contradictions of the global industrial model, to produce a better ecological balance at both the local and the global levels, and to improve the democratic character of energy governance. In addition, we suggest a paradigmatic reading to better understand the cultural, political and socio-economic implications of the two models.
\end{abstract}

Keywords: biofuel; global industrial model; regional agrarian model; local scale; short chain; North Western Europe

Article history: Received 14 November 2016; Accepted 30 November 2017; Published 31 December 2017

\section{Introduction}

Renewable energy (RE) is proposed by world agencies and governments as a solution to global climate change: on a global scale (to cut $\mathrm{CO}_{2}$ emissions and mitigate climate change); on a national scale (to reduce energy supply costs, diversify fuel resources, diminish dependence on fossil fuel imports, enhance the security of the energy supply and address fossil fuel scarcity); and on a regional scale (to improve rural economies). Referring especially to the "southern" countries, RE is promoted as a way to generate employment and income, the opportunities for foreign investment, development in depressed areas, new taxes and foreign exchange revenues (Sawyer, 2008). At other scales, RE, especially agroenergy and biofuel, can produce socio-economic and environmental problems (deforestation and destruction of biodiversity, dependence on imports, food insecurity and rural poverty), which can lead to social unrest and social conflict. Several researchers have already noted the shortcomings of the large-scale production and export of first-generation biofuels (ethanol and biodiesel) (e.g. Altieri, 2009; Ponti and Guitierrez, 2009; Rathmann et al., 2010; Van der Horst and Vermeylen, 2011). The public debate has focused on the overall carbon footprint and rarely includes spatial analysis of environmental and social impacts (Secchi et al., 2011). This model is promoted by international organisations (the United Nations, G8 bio-energy partnership, World Trade Organization, etc.), the European Union (EU), the United States of America (USA) and other governments, resulting in considerable investments in export-oriented biomass and biofuel (Faaij, 2011), reinforced by interconnected market/economic factors, such as differences in production costs across nations (Lamers et al., 2011). Economic and political elites believe that global biofuel production and consumption will mitigate climate change and enhance energy security (Mol, 2007).

In the last decade, biofuel production and global trade have grown exponentially. Production has increased from less than 30 petajoule (PJ) in 2000 (0.8 Mtonnes) to 572 PJ (15.2 Mtonnes) in 2009 for biodiesel, from $340 \mathrm{PJ}$ in 2000 to over 1,540 PJ in 2009 for fuel ethanol (Lamers et al., 2011), and currently biofuels (biodiesel and ethanol) represent the vast majority of the renewable share of global energy demand for transport, providing around $4 \%$ of world road transport fuel (REN21, 2017). The prevailing trend is for biofuel streams to move from south to north on a global scale. Ethanol is produced primarily in Brazil, whereas the largest biodiesel producers are Argentina, Malaysia and Indonesia, and both fuels are exported mainly to the EU and the USA (Lamers et al., 2011; Mol, 2010).

\footnotetext{
${ }^{\text {a }}$ Department of Economics, University of Foggia, Italy

b Department of Geography, University of Liège, Liège, Belgium (*corresponding author: S. Schmitz, e-mail S.Schmitz@uliege.be)
} 
In Europe, the EU supports biofuel primarily for the purposes of $\mathrm{CO}_{2}$ emissions reduction, energy security, diversification and increasing farmers' incomes. In 2015, $79.4 \%$ of biofuel consumption for transport came from biodiesel, 19.5\% from bioethanol and the rest (1.1\%) from biogas (EurObservER, 2016). Germany, followed by France and Spain, are the largest European producers and among the top 16 countries for biofuel global production (REN21, 2017). The main consumers of biodiesel in the EU are France, Germany and Italy (49\% of the total) (EurObservER, 2016). In recent years, we have also observed an increase in vegetable oil imports from other EU countries and from the global market, and some countries have become increasingly dependent on imports (Junginger et al., 2008; Kalt and Kranzl, 2012).

This paper analyses local initiatives to produce biofuel in North Western Europe and discusses their efficiency. Do local initiatives better fit the aims of sustainable development? We focus on second-generation biofuels and investigate the following research questions:

1. Is it possible to define a production-distributionconsumption model to avoid the contradictions and problems produced by the global model?;

2. What are the location criteria that must be met by a site to reduce or offset negative local impacts?; and

3. Is it possible to define an optimal spatial scale for bioenergy development, i.e. the most pertinent spatial scale at which the contradictions and problems produced by the global model can be overcome and allow for the democratisation of energy governance?

Geographers have a long tradition in local impact assessment, highlighting scale effects and looking for the best locations. As human geographers, we insist that bioenergy assessment analyses the whole production process from a holistic point of view, including the different locations and social and environmental implications at various scales.

This paper is structured as follows: after background on the impact of the global industrial model (section 2.1), the territorial dimension and the spatial scale (section 2.2), section 3 presents local initiatives in North Western Europe. These last are analysed (section 4) and their efficiency is questioned (section 5). In particular, we examine local biofuel production (section 4.1), the location and social acceptance issue (4.2), the entrepreneurial and territorial models (4.3), and local scale and governance (4.4). We propose a comparison between the global and the regional scale models in section 5.1 and, finally, we present a regional agrarian model (section 5.2).

\section{Theoretical background}

The assessment of biofuel as a sustainable energy source depends on the entire process (Cockerill and Martin, 2008). Nevertheless, we lack information about the complete cycle and its impact at different scales (German et al., 2010), and these assessments raise ethical concerns regarding equity, biodiversity and the future of mankind (Gamborg et al., 2012).

\subsection{The impact of the global industrial model}

The global model of large-scale production and longdistance transport concerns both the supply of raw materials and the countries where biofuel is consumed. This model creates ecological impacts and contradictions relating to environmental, socio-economic and geopolitical aims (Ponti and Gutierrez, 2009; Russi, 2008). Various studies, referring particularly to first-generation biofuels but also to biogas produced according to a profit logic and without connections to local communities (Carrosio, 2013), show the impacts on environmental and socio-economic organisation (Altieri, 2009; de Carvalho and Marin, 2011; Naylor, 2007; Sawyer, 2008). Several studies underline changes in agriculture, the alteration of land use dynamics, food insecurity and an increase in food prices (Azar and Larson, 2000; Rathmann et al. 2010). Other research outlines several interrelated problems: the spatial relations between deforestation and biofuel production (Gao et al., 2011); the high energy and water costs of crop irrigation and production (Dalla Marta et al., 2011; Pérez et al., 2011; Williams et al., 2012); threats to biodiversity (Rowe et al., 2009; Sullivan et al., 2011); the loss of local control over territories and ecosystems and the land grab phenomenon (Cotula, 2012; Dauvergne and Neville, 2010; Duvail et al., 2012; Vermeulen and Cotula 2010); territorial disputes (Amigun et al. 2011; Fernandes et al. 2010); involvement and tensions with indigenous communities (Colbran, 2011; Hazlewood, 2012; Montefrio and Sonnenfeld, 2013); connections to the climate dimension (Jensen and Andersen, 2013; Tsao et al., 2012); and direct questioning of the sustainability of these REs (Levidow and Paul, 2010; Zeller and Grass, 2008).

The negative territorial impacts of the global industrial model observed in the above- mentioned literature have been represented in a matrix (Tab. 1), with respect to: (a) the different phases of the production-distribution-consumption chain; (b) a macro-typology of the impacts (agrarian environmental, landscape, socio-economic and geopolitical); and (c) the main spatial scales at which the impacts appear and can be wholly valuated, as well as the level at which the phenomena are more important and/or more dangerous (also as interpreted in the analysed literature).

Nevertheless, if a global industrial model exists, it should present positive impacts as well. These impacts are related to the enrichment of huge companies, including petrol companies, the weakening of fossil fuel dependency, and the development of new economic activities. Dependence on imports often occurs, however, which conflicts with the objective of energy autonomy, and the people who pay the environmental costs (local inhabitants) are not the same as those who reap the economic benefits (large corporations). This can become a social justice problem, and social tensions can conflict with the aims of sustainable rural development. The global industrial model is characterised by separate places of production and consumption, which are rural areas and urban areas, respectively, and on the global level, southern countries and northern countries, respectively. This separation leads to the delocalisation of resource use (fossil fuels, soil and water for production) and the rescaling of pollution, as in more traditional sectors of global industry (Gupta and Dermibas, 2010). The use of biofuel for transport or heating can improve air quality at the local or regional level (for example, the effect can be important in towns) but worsen the net global level of greenhouse gases emitted in the production and transport phases.

\subsection{The territorial dimension and the spatial scale}

The international discussion pays little attention to the territorial dimension of biofuel production and, thus, to the relations between biofuel production chains and territorial organisation at different spatial scales (Puttilli, 2009; Puttilli and Tecco, 2012). Bridge et al. (2013) call for 


\begin{tabular}{|c|c|c|c|c|}
\hline \multirow{2}{*}{$\begin{array}{l}\text { Biofuel production } \\
\text { chain }\end{array}$} & \multicolumn{4}{|c|}{ Spatial scale } \\
\hline & Local & Regional & National & Global \\
\hline \multirow[t]{11}{*}{ Biomass production ${ }^{* *}$} & Loss of biodiversity & Deforestation & $\begin{array}{l}\text { High energy and water } \\
\text { consumption }\end{array}$ & $\begin{array}{l}\text { Degradation of the global } \\
\text { ecosystem }\end{array}$ \\
\hline & $\begin{array}{l}\text { Nutrient leaching and } \\
\text { soil erosion }\end{array}$ & $\begin{array}{l}\text { High energy and water } \\
\text { consumption }\end{array}$ & Concentration of lands & $\begin{array}{l}\text { GHG emissions } \\
\text { associated with direct } \\
\text { and indirect land uses }\end{array}$ \\
\hline & $\begin{array}{l}\text { Soil and water depletion } \\
\text { and pollution by } \\
\text { pesticides and chemical } \\
\text { fertilisers }\end{array}$ & Landscape changes & Increased price of lands & $\begin{array}{l}\text { Dependence on } \\
\text { industry and markets } \\
\text { for the upstream and } \\
\text { downstream phases of } \\
\text { production }\end{array}$ \\
\hline & $\begin{array}{l}\text { Simplification and } \\
\text { uniformity of landscape }\end{array}$ & $\begin{array}{l}\text { Alteration of land use } \\
\text { and its dynamics }\end{array}$ & Rural poverty & $\begin{array}{l}\text { Dependence of farmers } \\
\text { on biofuel corporations }\end{array}$ \\
\hline & $\begin{array}{l}\text { Changes in agricultural } \\
\text { products }\end{array}$ & $\begin{array}{l}\text { Loss of control } \\
\text { over territories and } \\
\text { ecosystems by local } \\
\text { people }\end{array}$ & $\begin{array}{l}\text { Competition among } \\
\text { alternative uses of } \\
\text { biomass for food, feed, } \\
\text { fibre and fuel }\end{array}$ & $\begin{array}{l}\text { Increase of agricultural } \\
\text { products (such as wheat, } \\
\text { corn, etc.) and food prices } \\
\text { (such as pasta, bread, } \\
\text { etc.) }\end{array}$ \\
\hline & Land use changes & $\begin{array}{l}\text { Tensions with indigenous } \\
\text { communities }\end{array}$ & Food insecurity & $\begin{array}{l}\text { Competition between } \\
\text { food and non-food } \\
\text { production over land use }\end{array}$ \\
\hline & $\begin{array}{l}\text { Scarce or absent } \\
\text { relations with the local } \\
\text { agricultural chain }\end{array}$ & & & Land and water grabbing \\
\hline & $\begin{array}{l}\text { High energy and water } \\
\text { costs }\end{array}$ & & & \\
\hline & $\begin{array}{l}\text { Competition over scarce } \\
\text { resources (water, soil, } \\
\text { etc.) }\end{array}$ & & & \\
\hline & $\begin{array}{l}\text { Loss of land, livelihoods } \\
\text { and traditional ways of } \\
\text { life in local communities }\end{array}$ & & & \\
\hline & $\begin{array}{l}\text { Disputes with local } \\
\text { communities }\end{array}$ & & & \\
\hline \multirow[t]{5}{*}{ Biomass processing } & $\begin{array}{l}\mathrm{CO}_{2} \text { emissions and air } \\
\text { pollution }\end{array}$ & $\begin{array}{l}\text { Alteration of regional } \\
\text { climate }\end{array}$ & Dependence on imports & $\begin{array}{l}\text { Increasing greenhouse } \\
\text { effect and climate change }\end{array}$ \\
\hline & Landscape changes & & & \\
\hline & Public health & & & \\
\hline & Fire concerns & & & \\
\hline & $\begin{array}{l}\text { Few or absent relations } \\
\text { with local actors }\end{array}$ & & & \\
\hline Biomass transportation & & $\begin{array}{l}\mathrm{CO}_{2} \text { emissions and air } \\
\text { pollution }\end{array}$ & $\begin{array}{l}\mathrm{CO}_{2} \text { emissions and air } \\
\text { pollution }\end{array}$ & $\begin{array}{l}\text { Increase in greenhouse } \\
\text { effect and climate change }\end{array}$ \\
\hline \multirow[t]{2}{*}{ Biofuel manufacturing } & $\begin{array}{l}\mathrm{CO}_{2} \text { emissions and air } \\
\text { pollution }\end{array}$ & & & \\
\hline & Landscape changes & & & \\
\hline Biofuel distribution & & $\begin{array}{l}\mathrm{CO}_{2} \text { emissions and air } \\
\text { pollution }\end{array}$ & $\begin{array}{l}\mathrm{CO}_{2} \text { emissions and air } \\
\text { pollution }\end{array}$ & $\begin{array}{l}\text { Increase in greenhouse } \\
\text { effect and climate change }\end{array}$ \\
\hline Biofuel consumption & & & Dependence on imports & \\
\hline
\end{tabular}

Tab. 1: Global industrial model: potential territorial impacts of the biofuel production chain at different spatial scales* (Notes: "the different spatial scales refer to the main spatial scales at which the impacts appear and can be wholly valuated, as well as the level at which the phenomena are more important and/or more evident and/or more dangerous; ** biomass production refers especially to monoculture for first-generation biofuels in Southern hemisphere countries)

Sources: authors' conceptualisation based on Altieri (2009); Amigun et al. (2011); Azarand Larson (2000); Carrosio (2013); Colbran (2011); Cotula (2012); Dalla Marta et al. (2011); Dauvergne and Neville (2010); de Carvalho and Marin (2011); Duvail et al. (2012); Fernandes et al. (2010); Gao et al. (2011); Gupta and Dermibas (2010); Hazlewood (2012); Levidow and Paul (2010); Montefrio and Sonnenfeld (2013); Naylor (2007); Jensen and Andersen (2013); Pérez et al. (2011); Ponti and Gutierrez (2009); Rathmann et al. (2010); Rowe et al. (2009); Russi (2008); Sawyer (2008); Sullivan et al. (2011); Tsao et al. (2012); Vermeulen and Cotula (2010); Williams et al. (2012); Zeller and Grass (2008) 
more attention to be paid to the geographies of the energy transition. In particular, location, landscape, territoriality, spatial differentiation, scaling and spatial embeddedness are identified by these authors as necessary concepts to reflect the spatiality of energy transitions, which is too often analysed as single case studies. The production of bioenergy occurs at different scales (Walker and Cass, 2007). Depending on the scale and the places of production and consumption, the economic, social and environmental implications at the global, regional and local scales vary significantly. This diversity raises spatial equity questions (Pasqualetti, 2000).

The number of studies investigating local biofuel has grown since 2008 and exponentially so in the past few years. In these studies, biofuel is viewed essentially as a business (Tateda et al., 2011; Voytenko and Peck, 2012), and territory, which is at the centre of related research, is perceived as the key to achieving particular goals (with respect to second-generation biofuels as well). For example, territory - at each spatial scale - can be analysed to serve an objective such as the identification or evaluation of agricultural residue, residual biomass and/or other products for bioenergy production (Beccali et al., 2008; FerreiraLeitao, 2010; Goltsev et al., 2010; Mabee and Mirck, 2011; Tricase and Lombardi, 2009; Yan, 2008). Policies for biofuel development (Borras et al., 2011; Hultman et al., 2012) in rural areas are analysed to verify opportunities, through the development of biomass, to diversify economies and increase farmers' incomes (Mwakaje, 2012; Zolin, 2011). On the other hand, some recent studies question the scale of production (Carrosio, 2013; Cotula, 2012; Monteleone et al., 2009) and pay more attention to the local acceptance of biogas plants (Kortsch et al., 2015; Schumacher and Schultmann, 2017; Soland et al., 2013). Local systems based on ecological principles have been analysed (Altieri, 1999; Huttunen, 2011), as have the driving forces of and attitudes towards biofuel diversification (Frantal and Prousek, 2016). A theoretical agro-territorial energy system with energy production coming from local biomass has also been proposed (Tritz, 2012).
Van der Horst and Vermeylen (2011) established a connection between the spatial scale and the social impacts of biofuel production, showing that domestic production and consumption in so-called developed countries produce a relatively minor social impact in comparison to international chains in so-called developing countries. Social impact is defined as "the consequences to human populations of any public or private actions that alter the way in which people live, work, play, relate to one-another, organise to meet their needs and generally cope as members of society. The term also includes cultural impacts involving change to the norms, values, and beliefs that guide and rationalise their cognition of themselves and their society" (Burdge et al., 2003). To avoid the greatest impacts and contradictions arising from energy-crop monocultures and the globalscale import-export of biomass and biofuel, it is advisable to manage agricultural residue and manure at the local level with a short chain with respect to both spatial (short distance) and organisational aspects (without brokers). A short chain refers to both the production-transformationconsumption levels and the technological, economic, financial, social and political levels.

\section{Methodology}

The methodology used in this study is essentially inductive, based on qualitative and quantitative analysis and a multi-scale approach. Specifically, it is grounded in the following: (a) indirect observation: the geographic literature, bibliographies, websites, laws and statistical data - on different spatial scales - concerning bioenergy; and (b) direct observation: research in the field with interviews and visits to biogas sites and farms.

First, we studied the situation in Belgium, specifically in the Walloon Region, analysing the initiatives of the Regional Network for Rural Development. This network, which stems from the Leader program, targets endogenous development based on local resources. We looked for local agro-energy models and interviewed the facilitator of

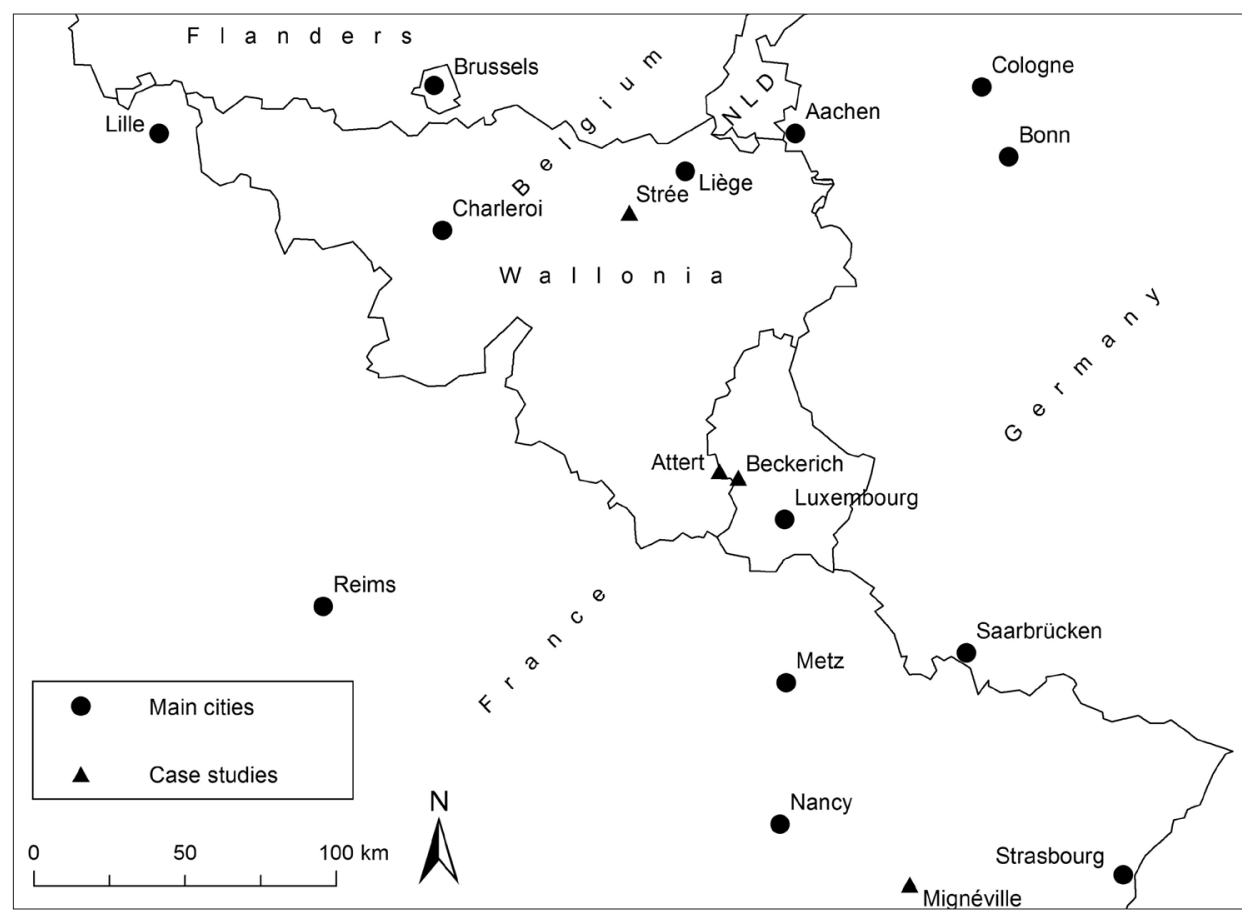

Fig. 1: Locations of the case studies

Source: authors' elaboration 
agro-energy development projects in the Walloon Region. The facilitator gave us information and data regarding the eighteen local-scale biogas units in the region. Based on desk research and discussions with the facilitator and Belgian scholars, we decided to focus on the case of a European project aimed at developing biogas production in the Greater Region, a cross-border region in the Rhineland supported by INTERREG programmes that cover 11 million inhabitants. An interesting aspect of the project is that it is conceived on a regional scale (the Greater Region) but developed on a local scale in each country (Belgium, France, Germany and Luxembourg), with very different conditions, processes and, thus, results. We consider this feature very important in observing the weaknesses and strengths of each case. Thus, we study three operative cases that are part of this project.

These case studies pertain to second-generation biofuels and are characterised by a biogas cogeneration system developed in rural areas. Each case produces electricity and heat and uses by-products such as digestate for compost. The cases are located in Attert (Walloon Region, Belgium), Beckerich (Luxembourg) and Migneville (Vosges, France) (see Fig. 1). We also added a developing project in Strée (Belgium) promoted by the "Pays des Condruses" Local Action Group (LAG), because its institutional objectives included territorial participation, an essential aspect of our research. This last case is the reason we left out the cases and projects in the Walloon Region that were missing social participation.

For each case, we studied indirect sources, identified and interviewed six key actors promoting the initiatives, namely, the Director of the "Pays des Condruses" LAG, the President of the "Au pays de l'Attert" Association, the holder of the Faascht farm (Attert), the Mayor of Beckerich, the President of the "D'millen" Association, the Mayor of Migneville and the owner of an enterprise named "Bio-recycle". The interviews were conducted during the summer of 2013.

The interview questions were developed using an historical-geographic and problematic approach, which focussed attention on processes, spatial and relational aspects, problems and critical points. Thus, we constructed an analytical matrix. In the columns, we have indicated the four main macro-aspects (local development process; institutional, financial, scientific, social and cultural conditions; technical, financial, governmental and territorial problems; and critical points regarding raw materials, energy valorisation and waste) and related questions. Valorisation is used in this report to indicate 'value added' from the process. In the cells, we summarised the responses. Thus, by reading the matrix, we obtain information regarding each case and can immediately compare their main aspects. The interviews were composed of 30 general questions and specific requests referring to each case. The interviews were recorded and analysed separately by two researchers (the authors), and the validity of the information was verified by previously analysed indirect sources and the official data received or collected.

\section{Results: Local biofuel initiatives}

\subsection{Local biofuel production}

The peculiar features of each case study are summarised in the following matrix (Tab. 2). The analysis of the technical characteristics and of the interviews allows the identification of relevant differences from the global industrial model. First, the local biofuel initiatives analysed do not use raw materials produced specifically for industry (as is the case of first-generation biofuels) but valorise the residues of primary sectors, such as agriculture (pruned branches, straw, etc.), livestock farming (manure) and forestry. Agro-food industry waste can also be included. Agricultural residues are thought to have substantial potential for the development of bioenergy in numerous countries (in EU-27, the estimate is approximately $250 \mathrm{M}$ dry tonnes/year on average (Scarlat et al., 2010). These residues are characterised by seasonal production and high territorial diffusion and can provide the following benefits:

1. the recovery and valorisation of residues from the agricultural, livestock breeding and agro-food industries (which would otherwise become waste with economic and environmental costs);

2. the "stabilisation" of effluents with harmful health effects (such as pathogenic bacteria) and offensive odours (especially from the spreading of manure onto fields);

3. the diversification of agricultural activity;

4. a reduction in fertilising and heating costs; and

5. increased incomes from selling electricity and heat.

All the cases studied in the field and the 16 cases in Walloon are regionally embedded. On the one hand, raw materials are obtained on a local (manure) or regional scale (agro-food industry waste), and on the other hand, heat and compost add value at the local scale (and in some cases, at the regional scale). Only electricity is valorised on a national scale because producers are obliged by law to sell it to the domestic network. Because manure and agricultural residue do not have high enough energy values to warrant transportation over large distances, the level of supply is critical. For example, in the case of the Faascht farm, we found that one ton of manure produces just $20-25 \mathrm{~m}^{3}$ of biogas, whereas one ton of chocolate waste can produce $60-80 \mathrm{~m}^{3}$. Thus, transport would require more energy than is produced by the biomass being moved. Moreover, the transport costs for bioenergy are higher on average than those for fossil energy because of the type of transport, e.g. by road for the former and by railroad, sea, river or pipeline for the latter (Tritz, 2012).

These initiatives can be well developed in rural areas, where there are large farmers and breeders or many small farmers and breeders. They can also create a virtuous circle between breeders who have large amounts of manure to eliminate and farmers who need fertiliser. In this way, it is possible to avoid waste (and the resultant potential contamination) by transforming them into raw materials for biofuel production; further, export-import activities and the consequent air pollution are avoided. Thus, agro-food wastes (that produce higher quantities of energy) coming from a regional scale can add to and optimise energy production from plants. Nevertheless, it is important to evaluate this option for each case in terms of the economic and energy costs of transportation and the subsequent environmental load.

\subsection{The location and social acceptance issues}

The local initiatives analysed can produce impacts and problems, especially at the local level, resulting in 'not in my back yard' (NIMBY) phenomena. Based on rational choice theory, NIMBY theory states that local inhabitants support energy transition but do not want to be confronted with the real or perceived negative effects 


\begin{tabular}{|c|c|c|c|c|}
\hline & $\begin{array}{c}\text { "Pays des Condruses" } \\
\text { LAG (BE) }\end{array}$ & $\begin{array}{c}\text { Faascht farm Attert } \\
\text { (BE) }\end{array}$ & Beckerich (LU) & $\begin{array}{l}\text { Bio-recycle farm } \\
\text { Migneville (FR) }\end{array}$ \\
\hline Biomass resources & $\begin{array}{l}\text { Manure, lawn cuttings, } \\
\text { wheat, corn, residues of } \\
\text { olives and flours from } \\
\text { local sources }\end{array}$ & $\begin{array}{l}\text { Manure from farms } \\
(6,000 \mathrm{t}) \text {. Agro-industry } \\
\text { wastes coming from } \\
\text { the sub-regional level } \\
(10,000 \mathrm{t})\end{array}$ & $\begin{array}{l}\text { Manure, agricultural } \\
\text { wastes and corn from } \\
\text { local sources }\end{array}$ & $\begin{array}{l}\text { Manure from farms } \\
(1,800 \text { t). Agro-industrial } \\
\text { wastes from within } 100 \\
\mathrm{~km}(3,700 \mathrm{t})\end{array}$ \\
\hline \multirow[t]{3}{*}{ Biomass valorisation } & Heating (for citizens) & Heating (for farm) & Heating (for citizens) & $\begin{array}{l}\text { Heating (for farm, six } \\
\text { houses and the school) } \\
\text { and the drying of forage }\end{array}$ \\
\hline & \multirow[t]{2}{*}{$\begin{array}{l}\text { Compost for fertiliser } \\
\text { (for farmers) }\end{array}$} & $\begin{array}{l}\text { Electric energy (sold to } \\
\text { the national network) }\end{array}$ & $\begin{array}{l}\text { Electric energy (sold to } \\
\text { the national network) }\end{array}$ & $\begin{array}{l}\text { Electric energy (national } \\
\text { network) }\end{array}$ \\
\hline & & $\begin{array}{l}\text { Fertiliser (for farm, local } \\
\text { farmers and sale) }\end{array}$ & Fertiliser (for farmers) & Fertiliser (for farms) \\
\hline Promoters & $\begin{array}{l}\text { LAG - The LAG aims } \\
\text { to create a citizen-based } \\
\text { society to valorise the } \\
\text { local agricultural wastes } \\
\text { and generate heat and } \\
\text { fertilisers }\end{array}$ & $\begin{array}{l}\text { Farmer and association - } \\
\text { The farm produces milk } \\
\text { and cheese. The "Pays de } \\
\text { l'Attert" is an association } \\
\text { engaged in the cultural } \\
\text { and environmental field }\end{array}$ & $\begin{array}{l}\text { Farmers and } \\
\text { municipality - Beckerich } \\
\text { municipality, composed of } \\
\text { eight small villages, has } \\
\text { collaborated strictly with } \\
\text { the farmers and citizens }\end{array}$ & $\begin{array}{l}\text { Farmer - The Bio-recycle } \\
\text { farm produces organic } \\
\text { forage and milk }\end{array}$ \\
\hline \multirow[t]{3}{*}{ Objectives } & Rural development & $\begin{array}{l}\text { Farmer: economic, } \\
\text { agronomic and } \\
\text { environmental aims }\end{array}$ & $\begin{array}{l}\text { Farmers: economic, } \\
\text { agronomic and } \\
\text { environmental aims }\end{array}$ & $\begin{array}{l}\text { Environmental, economic } \\
\text { and agronomic aims }\end{array}$ \\
\hline & Environmental aims & $\begin{array}{l}\text { Association: } \\
\text { environmental aims }\end{array}$ & $\begin{array}{l}\text { Municipality: } \\
\text { social, political and } \\
\text { environmental aims }\end{array}$ & $\begin{array}{l}\text { Autonomy from market } \\
\text { in terms of fertilisers }\end{array}$ \\
\hline & $\begin{array}{l}\text { EU targets for renewable } \\
\text { energy development }\end{array}$ & & & Energy transition \\
\hline Installation & Collective & Private & Collective & Private \\
\hline Institutional conditions & $\begin{array}{l}\text { Regional and local level: } \\
\text { favourable }\end{array}$ & $\begin{array}{l}\text { Regional: favourable } \\
\text { Local level: indifferent }\end{array}$ & $\begin{array}{l}\text { National and local level: } \\
\text { strong political will }\end{array}$ & $\begin{array}{l}\text { National level: } \\
\text { favourable }\end{array}$ \\
\hline \multirow[t]{3}{*}{ Financial conditions } & $\begin{array}{l}\text { Government funding } \\
\text { (EU, municipality) }\end{array}$ & $\begin{array}{l}\text { Government funding } \\
\text { (Walloon region) }\end{array}$ & $\begin{array}{l}\text { Government funding } \\
\text { (municipality, state) }\end{array}$ & Government funding \\
\hline & $\begin{array}{l}\text { Farmers and citizens } \\
\text { with money and bank } \\
\text { loans }\end{array}$ & Farmer with a bank loan & Farmers (by bank loan) & Bank loans \\
\hline & & & $\begin{array}{l}\text { Income from the sale of } \\
\text { heat }\end{array}$ & \\
\hline Scientific conditions & Favourable & Favourable & Favourable & Absent \\
\hline Social conditions & Favourable & Indifferent & Collaborative & Indifferent \\
\hline Cultural conditions & Favourable & Indifferent & Favourable & Indifferent \\
\hline Citizens attitude & Passive acceptance & Indifferent or mistrustful & Positive and collaborative & Indifferent or mistrustful \\
\hline \multirow[t]{2}{*}{$\begin{array}{l}\text { Engagement of local } \\
\text { community }\end{array}$} & Stakeholder approach & $\begin{array}{l}\text { Communication post- } \\
\text { project }\end{array}$ & Public meetings & $\begin{array}{l}\text { Communication post- } \\
\text { project }\end{array}$ \\
\hline & & $\begin{array}{l}\text { Farmers bring their } \\
\text { manure }\end{array}$ & $\begin{array}{l}\text { Consultative } \\
\text { commissions }\end{array}$ & $\begin{array}{l}\text { Farmers bring their } \\
\text { manure }\end{array}$ \\
\hline \multirow[t]{3}{*}{ Positive local impacts } & $\begin{array}{l}\text { Reduction of offensive } \\
\text { odours }\end{array}$ & $\begin{array}{l}\text { Virtual energy } \\
\text { independence }\end{array}$ & Employment & Employment (2 units) \\
\hline & Improving water quality & $\begin{array}{l}\text { Employment ( } 2.5 \text { units) } \\
\text { and satellite activities }\end{array}$ & Reduction of tariffs & $\begin{array}{l}\text { Reduction of offensive } \\
\text { odours }\end{array}$ \\
\hline & & & $\begin{array}{l}\text { Money remains at the } \\
\text { local level }\end{array}$ & \\
\hline Negative local impacts & Road traffic & Road traffic & No & Road traffic \\
\hline Technical problems & Yes & Yes & Yes & Yes \\
\hline Governance problems & Yes & Yes & No & Yes \\
\hline Financial problems & Yes & Yes & Yes & No \\
\hline
\end{tabular}

Tab. 2: Characteristics of the case studies

Source: authors' elaboration 
in their neighbourhood (Soland et al., 2013). As the case studies have shown, the main and recurrent impacts are road traffic, landscape impacts, safety concerns and burst pipes. The same cases, however, present possible solutions with reference to the organisation of supply phases and the location of processing plants, as well as information and communication initiatives.

It is important to consider that for the Faascht and Biorecycle farms, the increase in traffic of concern was two trucks each week. To reduce road traffic, it is essential to organise the biomass and compost supply phases. In reality, as the Beckerich case demonstrates, if the two phases occur at the same time (leaving biomass and taking compost already produced), transport can be decreased by half, reducing road traffic and air pollution and saving money. To avoid the landscape impacts, processing plants could be totally or partially covered with earth. In this way, the plant cannot be seen from the street, as in the case of the Bio-recycle farm in Migneville. If such an arrangement is not possible (for example, in the presence of groundwater), it is important to reduce the visual impact of biofuel units by planting trees and native vegetation. Furthermore, the stock area should be covered or surrounded by vegetation. To alleviate concerns about safety, burst pipes and tanks, it is important to localise the processing plant away from urban areas and away from houses. As the Faascht farm and the Becherich case have shown, a distance of one $\mathrm{km}$ from the nearest house and $1.5 \mathrm{~km}$ from the nearest town is considered sufficient. Another important aspect is communicating with inhabitants and organising public conferences with experts to make clear the real risks associated with the processing plant. In fact, in the case examined in the Walloon Region, where the plant is in town (Surice farm), there was social and political opposition to both the offensive odour and the potential for burst pipes.

Electricity must be sold via the official distribution network operator in most European countries (which may lead to difficulties such as under-capacity of transport, competition among producers, high costs, and poor perception by locals of local energy production). In these four case studies, however, heat appears to be more profitable, especially because of stronger support from public authorities in the three studied countries. Because of the difficulty of transporting heat, it may be advisable to locate plants close to large consumers of heat.

As Wolsink (2007) and Schmitz et al. (2012) have noted, the process of the project is often more important than the plant. Who is leading? Who invests? How is the project discussed with citizens? Who seems to win and who seems to lose? The literature emphasises the importance of factors such as the perception of justice, especially the balance of perceived costs and benefits, and trust in the plant operator, as very influential factors to explain local acceptance (Grannec et al., 2016; Schumacher and Schultmann, 2017; Soland et al., 2013).
Contrary to other studies on the acceptance of biogas plants (Kortsch et al., 2015; Schumacher and Schultmann, 2017; Soland et al., 2013), we heard very little mention of smell. This may be explained both by the evolution of the technology, and by the use, in the four studied farms, of a mix of cow manure and agro-industrial or agricultural wastes. Indeed, the biomethanisation of cattle manure substitutes for the spreading of manure on the fields and so reduces the odours (Mignon, 2009). Grannec et al. (2016) pointed out that, in Brittany, the fear of accidents related to road traffic or the presence of gas has more influence than the odours or the noise.

\subsection{Entrepreneurial and territorial models}

The case studies can be divided into two types depending on the main actors, their interests, their aims, and the direct benefits and advantages, which can be private or collective. Hence, we can define two production/ consumption models: the entrepreneurial model and the territorial model (Tab. 3)

The entrepreneurial model includes an enterprise and its economic and agronomic aims. The economic objectives are both "active", meaning an increase of incomes (for example, through energy production and sale) and "passive", that save money (for example, reducing fertiliser and heating costs). The agronomic objectives are to obtain high-quality compost and nourishing forage rich in protein. The territorial model includes the collective and its socioeconomic, political and environmental objectives, such as reducing tariffs, achieving energy autonomy (namely the ability to produce energy to satisfy the local energy demand without energy import), realising agricultural diversification, decreasing the use of nitrates, and protecting groundwater and soil. In theory, the territorial model could achieve the ideal zero environmental impact and a closed-loop system if raw materials came only from the farmer collective and compost, heat and electricity are valorised only by this collective.

The entrepreneurial model can be "associative" if it is led by a group of entrepreneurs and experts (as is the case with the Faascht farm) or "familial" if it is run mainly by a family (for example, the Bio-recycle farm). The territorial model can be "participated" if there are different actors who participate (as is the case with the "Pays des Condruses" LAG), whereas the model is "participative" when there are institutional mechanisms enabling and supporting engagement and participation by the whole community (as in the Beckerich case). The presence of raw materials alone, however, is not sufficient to form a territorial district. To this end, local social relations are fundamental. These relations can refer to public subjects, private subjects, formal networks or informal networks, which can act as collective actors to identify common objectives and implement a project to develop the potential of a territory.

Production / consumption models

\begin{tabular}{lcc}
\hline Model & Entrepreneurial & Territorial \\
Typology & associative & familial \\
Objectives & economic, agronomic & participated \\
\hline
\end{tabular}

Tab. 3: Entrepreneurial and territorial models of biofuel production/consumption

Source: authors' conceptualisation 
Within the entrepreneurial model - as in the cases of the Faascht and Bio-recycle farms - it is difficult to achieve independence of supply at the level of a single enterprise because of a processing plant's technical capacities:

"For example, the farm is not self-sufficient in biomass supply. But the farm is independent in practice by using the waste of cows, by drying the fodder thanks to the heat produced by biomethanisation (food self-sufficiency for the cows); by fertilising the land with the compost produced from the digestate (fertiliser autonomy); by heating the buildings thanks to the heat produced by the biomethanisation. It is also independent, from a virtual point of view, because the electricity produced and sold to the national grid is more than the needs of the farm" (Mr. Claudepierre, Bio-recycle farm, Migneville).

In reality, at the farm level and with the aim of making biofuel production economically convenient, the processing plant may require more raw materials than those supplied by the farm's activity. Thus, if a farm wanted to reach autonomy with respect to fertiliser, heating and energy, it would have to sacrifice autonomy in terms of provisioning and would be obliged to use agroindustry wastes sourced at the regional level. The limit of the territorial model is the distance between farmers because manure and agricultural residue do not have large energy capacities. According to the interviews, if manure is transported more than $15 \mathrm{~km}$, more energy is consumed by transport than is produced by the manure.

Another important issue for both models is the use of compost. Compost should be used locally; however, in some cases, depending on the legal issues, it can be sold for economic revenue. A limit to the development of agrarian local initiatives is the need for huge investments. Considering that farmers do not have large amounts of capital and taking into account a general lack of bank credit (generally, banks do not lend money because of the long time required for a return on the investment), to collect capital for building plants, farmers must "open" the enterprise to external investors, changing the legal form and thus the aims of their original project. The case studies show four possible ways to avoid this risk: beginning with a small processing plant that requires modest investment (Bio-recycle farm), beginning only if the farm has sufficient capital or a high credit capacity (Faascht farm), engaging in a public collection ("Pays des Condruses" LAG), and receiving substantial public support (Becherich). Another requirement for autonomy is the technological skill of the local producers.

\subsection{The local scale and governance}

The local (meaning the face-to-face level) and the regional scales also seem to be the optimal spatial scales for creating more effective democratisation of energy governance, as the case studies have shown. In fact, at these scales, it is possible to develop an effective short chain (in terms of investment and funding from local farmers, consumers and citizens). In particular, the local scale can make it possible for both control and economic benefits to remain at the local level, while the regional may offer resources (for example, industrial wastes) that could be lacking at the local level, without producing the negative impacts or contradictions intrinsic to the other spatial scales (first and foremost the global level).
In these cases, there is a true re-appropriation of $\mathrm{RE}$ sources by certain people (as in the Faascht and Biorecycle farms), by a group of citizens (as in the "Pays des Condruses" LAG) or by the entire community (as in the case of Beckerich).

Referring specifically to local participation, the case studies have shown very diverse social and cultural conditions given similar institutional and financial conditions. In this regard, we observed that where people are indifferent (e.g. the Faascht farm in Attert and the Biorecycle farm in Migneville), the installations are private and there is no involvement by citizens (the inhabitants were informed via communications post-project and after the farms had opened their doors to visitors):

"Open days give the opportunity to visit the biomethanisation unit, the farm, we host a barbecue ... guiding tour. But, these activities happened after the project. There was no commitment of the population before the construction. Before, we used the local paper to inform about the project” (Marcel Nickers, Association 'Au Pays de l'Attert' a.s.b.l. ${ }^{1}$ Attert).

In contrast, where public opinions are favourable (e.g. the "Pays des Condruses" LAG and Beckerich), the projects are collectives and there is direct participation (by part or all of the community). For the two collective cases, we observed a substantial difference in citizens' general attitudes, namely, passive acceptance in the case of the "Pays des Condruses" LAG and a positive and collaborative approach concerning Beckerich. The first case involved a top-down project initiated by a local institution (LAG) and realised by stakeholder consultation; the second case involved a bottomup approach generated by public meetings and a consultative commission with strong political end engagement:

"First, we inform through meetings open to all residents, followed by field visits to enable people to realise ... We use also a local newspaper for the ongoing information (in several languages). Direct participation is achieved by the voluntary participation in the consultative committees of citizens; by taking part to the creation of a cooperative to manage a collective installation; by using public space for collective energy production" (Ms. Isabelle Bernard, President of the Association D'millen a.s.b.l., Beckerich).

The local scale should strengthen the acquaintance and the truth between stakeholders. Nevertheless, the literature underlines the fact that proper information and the possibility to participate actively in the project will boost acceptance (Schweizer-Ries, 2008; Van Rompaey et al., 2011).

\section{Discussion}

\subsection{The global versus regional scale model}

Because it avoids most of the problems and contradictions concerning environmental, agrarian, socio-economic and geopolitical aspects produced by the global industrial model, a regional scale model - referring to the maximum level of raw materials supply and products valorisation - seems to be the optimal spatial scale for developing bioenergy (Tab. 4).

The regional scale makes it possible to reduce $\mathrm{CO}_{2}$ emissions and other polluting substances resulting from the production and transport of biomass and biofuel over long

\footnotetext{
${ }^{1}$ The 'association sans but lucratif' (a.s.b.l.) ('association without lucrative purpose' in English) is the legal term for a 'not-forprofit association' in Belgium and some other French speaking countries.
} 
distances, reduce energy dependence on biomass or biofuel imports, prevent the loss of control over territories and ecosystems by local people due to water and land grabbing by biomass producers, reduce territorial disputes regarding alternative uses of land, and address conflicts related to defending territory from the interests of large corporations. If we interpret these models from a paradigmatic viewpoint, we can better understand their cultural, political, economic and spatial implications.

The global industrial model is based on the same paradigm of growth and the neoliberal logic of a global market and competition that characterise the exploitative policies of fossil energy sources. For most of the cases, this approach involves control over and intensification of the production cycle, the incrementalisation of productive factors, the abatement of production costs (especially with respect to labour costs) and an increasing distance among places of production, transformation and distribution. The long chain entails a further ecological burden from the energy consumed because of increased transport distances. Thus, the environmental and social costs are externalised and territorial organisations are affected. Referring to firstgeneration biofuels, this model is characterised by a very tight link between agriculture and industry and strictly market-oriented production. In this way, agriculture becomes a supplier of raw material for energy and is thus the weak link in the chain. Farmers are dispossessed of their original social role, becoming executors of commands dictated by the logic and interests of industry and crushed by market mechanisms. In contrast, we advocate a regional agrarian model.

\subsection{The regional agrarian model}

The regional agrarian model is based on a territorial logic arising from the perception-value-interest system of the people who inhabit the place. This model could produce a territorial distribution of small- to medium-sized plants and, consequently, energy independence from global markets (of fertilisers and energy) and, possibly, international politics.

Thus, the inhabitants of Beckerich have no economic or political concerns with respect to heating their houses. They have no concerns about biomass prices on the global market or about international geopolitical decisions, and the money that citizens pay for heat remains in the region:

\footnotetext{
"The price people paid is lower, but more importantly, it is a question of independence and autonomy with regard to the international market and politics. We say: 'Do you want to be dependent on Iraq and Saudi Arabia energy source or on nine councilors and farmers that you know?'. Then, people understand the issue of energy sovereignty. Become self-sufficient and not dependent, economically and politically, on who controls the resources and the energy market" (Mayor Camille Gira, Beckerich).
}

\begin{tabular}{|c|c|c|}
\hline & Global model & Regional model \\
\hline \multirow[t]{3}{*}{ Objectives of producers } & $\begin{array}{l}\text { Business: profit, expanding into innovative } \\
\text { sectors, penetrating or developing a new } \\
\text { market, public incentives }\end{array}$ & $\begin{array}{l}\text { Economic aims: both "active" (increased } \\
\text { income through energy production and sale) } \\
\text { and "passive" (saving fertilising, heating } \\
\text { and/or fuel costs); autonomy from the } \\
\text { market }\end{array}$ \\
\hline & & $\begin{array}{l}\text { Agronomic aims: high-quality compost; } \\
\text { better quality of soil and products }\end{array}$ \\
\hline & & $\begin{array}{l}\text { Environmental aims: reduction of nitrates; } \\
\text { safety of groundwater }\end{array}$ \\
\hline \multirow[t]{4}{*}{ Objectives of public authorities } & $\begin{array}{l}\text { Local scale: e.g. Public administration } \rightarrow \\
\text { royalties }\end{array}$ & $\begin{array}{l}\text { Political aims: energy autonomy, energy } \\
\text { transition and paradigm change, public } \\
\text { transport, rural development, diversification } \\
\text { of agricultural activity }\end{array}$ \\
\hline & $\begin{array}{l}\text { Regional scale: e.g. Region } \rightarrow \text { economic } \\
\text { development }\end{array}$ & $\begin{array}{l}\text { Social aims: reduction of tariffs and } \\
\text { accessible price for the poorest; increase in } \\
\text { farmers' incomes }\end{array}$ \\
\hline & $\begin{array}{l}\text { National scale: e.g. State } \rightarrow \text { strategic and } \\
\text { geopolitical interests }\end{array}$ & $\begin{array}{l}\text { Environmental aims: reduction of } \mathrm{CO}_{2} \\
\text { protection of biodiversity }\end{array}$ \\
\hline & $\begin{array}{l}\text { Continental scale: e.g. European Union } \rightarrow \\
\text { reduction of climatic change }\end{array}$ & \\
\hline Producers & $\begin{array}{l}\text { Mainly exogenous in the form of large } \\
\text { corporations (which can be directly linked } \\
\text { with the oil corporations) }\end{array}$ & $\begin{array}{l}\text { Basically endogenous (private, public or } \\
\text { collective actors) and informal and formal } \\
\text { networks: cooperatives, consortiums, } \\
\text { associations, municipalities, LAGs }\end{array}$ \\
\hline Spatial perception & Space as a neutral and functional object/box & Space as a place and a house \\
\hline Scale of production & Global scale & Local, sub-regional and regional scale \\
\hline Biofuel chain & Long chain & Short chain \\
\hline Biomass origin & Global scale & Local, sub-regional and regional scale \\
\hline Main biomass resource & Monoculture, agroindustry wastes & $\begin{array}{l}\text { Manures, agricultural residue, agroindustry } \\
\text { residue }\end{array}$ \\
\hline Main biomass provisioning & By brokers and traders & By farmers \\
\hline
\end{tabular}

Tab. 4: Main elements of the global model and the regional model for biofuel production Source: authors' elaboration 


\begin{tabular}{|c|c|c|}
\hline & Global model & Regional model \\
\hline \multirow[t]{3}{*}{ Main biomass valorisation } & Electric energy & $\begin{array}{l}\text { Warmth for heating buildings and drying } \\
\text { forage }\end{array}$ \\
\hline & Biofuel for transport & Electric energy \\
\hline & Warmth for heating & Compost for fertilising \\
\hline Plant size & Large size & Small to medium size \\
\hline Ecological impact & Potentially strong & Potentially light \\
\hline Relation with the local agricultural chain & Scarce or absent & $\begin{array}{l}\text { A key point and a characteristic component } \\
\text { of this model }\end{array}$ \\
\hline Relation with local actors & $\begin{array}{l}\text { Little direct involvement (the only exception } \\
\text { may be for the biomass production) }\end{array}$ & $\begin{array}{l}\text { Local actors are the main subjects of the } \\
\text { production-transformation-consumption chain }\end{array}$ \\
\hline Main relations & $\begin{array}{l}\text { Vertical relations among production, } \\
\text { transformation and consumption areas }\end{array}$ & Horizontal relations among local actors \\
\hline Market & Organised on a global scale & $\begin{array}{l}\text { Non-existent or organised on local, sub- } \\
\text { regional and/or regional scales }\end{array}$ \\
\hline \multirow[t]{6}{*}{ Main positive local impacts } & Jobs & Energy independence \\
\hline & & Reduction of tariffs \\
\hline & & Jobs and satellite activities \\
\hline & & Money remains at the local level \\
\hline & & $\begin{array}{l}\text { Elimination of pathogenic bacteria and } \\
\text { offensive odours from effluents }\end{array}$ \\
\hline & & Improved water quality \\
\hline \multirow[t]{10}{*}{ Main negative local impacts } & Road traffic and air pollution & Road traffic \\
\hline & $\begin{array}{l}\text { Soil and water pollution by pesticides and } \\
\text { chemicals fertilisers }\end{array}$ & \\
\hline & High energy and water use & \\
\hline & Changing land use & \\
\hline & Deforestation & \\
\hline & Loss of biodiversity & \\
\hline & Competition over scarce resources & \\
\hline & Loss of control over territories from local people & \\
\hline & Social tensions & \\
\hline & Simplification of landscapes & \\
\hline
\end{tabular}

Tab. 4: continuing

Moreover, the regional agrarian model valorises agricultural and livestock breeding residue and by-products and realises public and private objectives. Public objectives are many and include: reducing greenhouse emissions throughout the chain of production; preventing emissions of $\mathrm{CH}_{4}$ (methane) from effluent manure warehousing; valorising agricultural, breeding and agroindustry wastes (which would otherwise be decomposed, incurring economic and environmental costs); saving energy (and reducing pollution) used to produce chemical fertilisers; being independent from mineral resources, such as potassium and phosphate, located outside of Europe; having energy autonomy; being energy independent from fossil fuel; and increasing social accessibility to energy (Cameron, 2014). As for the private benefits for farmers, the following are important: reducing the costs of the management of agricultural and breeding residues; realising a structural solution for manure management; saving heating and fertiliser costs; independence from chemical fertilisers and energy markets; improving the agronomic value of soils through mineralised nitrogen (which is better assimilated by plants); reducing the risks of nitrogen leaching and underground water contamination; reducing pathogens and offensive odours; increasing incomes from sales of heat and electricity; and the independence of agricultural activity through the use of its residues and by-products.

We should note that, at the local level and according to the political conditions in the cases analysed, energy independence is a "virtual independence". In fact, farmers are obliged by law to sell the energy produced to the national network, and people continue buying electricity from large corporations. Thus, there is an economic advantage for farms and a general environmental benefit, but there are no direct economic and political benefits for the local community.

From the case studies, we learned that these local initiatives have to interact with the regional level that waste and manure may need to be imported to economically use equipment, to achieve economic and/or financial equilibrium and to produce sufficient electricity and heat for the community. This requirement weakens the $\mathrm{CO}_{2}$ balance of production. Moreover, some uncertainty exists with respect to the market value of the waste involved in biomethanisation, which makes budgeting more complex. In addition, due to the general lack of bank credit in this 
sector, political support seems necessary for investment and development purposes. It could be argued that because of the multiple advantages for the local (and global) society, communities should support agrarian regional biogas producers or at least pay for their services.

Nonetheless, the local nuisances of biofuel plants should be mitigated. The main localisation criterion to reduce or eliminate negative local impacts is to choose a place for processing plants near areas of biomass production and heating consumption. In this regard, to reduce transport costs and increase net energy production, some studies suggest a distance of $10 \mathrm{~km}$ (to a maximum of $60 \mathrm{~km}$ ) between the collection/storage points and the energy conversion plants (Paiano et al., 2011). In France, heating is used in a local distribution network smaller than $10 \mathrm{~km}$ to avoid energy losses (Tritz, 2012). It is clear that the best organisational option is to utilise a short chain. Theoretically, processing plants could be located near production or consumption areas, at a point among production areas or at a point among production and consumption areas. If the choice is made only to minimise transport costs, we could use a spatial model for industrial location, beginning with Weber's model. If we also consider territorial impact and social acceptability (that is to say, that the plant's implementation has not to be opposed to the values, ideas and interests of the inhabitants as a whole), however, it is better to look for a rural area where biomass is produced, with measures to avoid landscape impacts. In fact, only in this case it is possible to alleviate public concerns regarding burst pipes and safety.

We also infer that if the initial cultural and social conditions are essential to determining the nature and typology of the initiative, the approach used for developing the project is not neutral with respect to the participation of local residents. As we see it, in the top-down process, engagement is at the level of stakeholders, whereas in the case of a bottom-up process, it is the community that participates. Thus, it is clear that real and strong political will is very important for creating the conditions necessary for the effective democratisation of energy governance. The main energy suppliers are facing four challenges (the four Ds): decreased consumption, decarbonisation, spatial deconcentration and digitalisation. Biofuel is foreseen as a necessary transitional energy within a global and national framework (Van Troye, 2016). Despite the well-known impacts, it should be an intermediate state before an international green electricity network. Changing the scale of the analysis suggests that another model of production and consumption may exist with a positive balance both at the global and local levels.

\section{Conclusions}

Starting from the limitations and paradoxes of the global industrial model of biofuel production, this study has analysed how other models could achieve a more balanced production from environmental, social and economic points of view. We define such a model as regional, referring to the maximum spatial scale for the origin of raw materials and the location of biomass valorisation to achieve economic equilibrium without losing environmental benefits. It is clear that to achieve the greatest advantage, agricultural residues and manure must be transformed and used in the place where they are produced. We define this model as agrarian based on its tight links with other agricultural activities, livestock breeding and the valorisation of their residues. The beneficial aspect is the transformation of waste into raw material for biofuels used primarily by farms and local communities, avoiding pollution and saving fertiliser, heating and power costs. To mitigate the negative impacts of this model, location in rural areas (away from houses) and in sites totally or partially covered with earth is crucial, as is the combined organisation of biomass and compost supply phases.

There is an urgent need to broaden our view of $\mathrm{RE}$ and to analyse the whole process and its impacts on different places. Beside technical and economic issues, social and environmental costs should be included to assess the performance of bioenergy. Location, landscape and spatial differentiation issues have gained the attention of researchers. Regional and local control need to be analysed as well. Through attention to the spatial embeddedness of bioenergy, we have attempted to contribute to the creation and implementation of models for energy production and consumption that are more suitable for current conditions.

\section{Acknowledgement}

The present work is a result of the authors' joint commitments. Specifically, the methodology and structure of the paper is the result of joint work; the interviews in the field and the bibliographical research were conducted mainly by M. Ciervo; the charts were created by S. Schmitz. Although the two authors approved the entire manuscript, $M$. Ciervo contributed to paragraphs 2, 3, 4.1, 4.3, 4.4 and 6; and they both contributed to paragraphs 1, 4.2 and 5. The research in the field has been supported and developed as part of the Strategic and Technological Advancement in Research on AgroEnergy Project of the University of Foggia (funded by the European Commission, Directorate-General for Research and Innovation, SP4 - Capacities, Coordination and Support Action, $7^{\text {th }}$ Framework Programme, Regpot 2011-1, Grant Agreement No. 286269). The authors have no other relevant affiliations or financial involvement with any organisation or entity with a financial interest in or financial conflict with the subject matter or materials discussed in the manuscript apart from those disclosed.

\section{References:}

ALTIERI, M. (1999): Applying agroecology to enhance the productivity of peasant farming systems in Latin America. Environment, Development and Sustainability, 1(3-4): 197-217.

ALTIERI, M. A. (2009): The Ecological Impacts of Large-Scale Agrofuel Monoculture Production Systems in the Americas. Bulletin of Science Technology \& Society, 29(3): 236-244.

AMIGUN, B., MUSANGO, J. K., BRENT, A. C. (2011): Community perspectives on the introduction of biodiesel production in the Eastern Cape Province of South Africa. Energy, 36: 2502-2058.

AZAR, C., LARSON, E. D. (2000): Bioenergy and land-use competition in Northeast Brazil. Energy for Sustainable Development, 4(1): 64-71.

BECCALI, M., COLUMBA, P., D'ALBERTI, V., FRANZITTA, V. (2009): Assessment of bioenergy potential in Sicily: a GIS-based support methodology. Biomass and Bioenergy, 33(1): 79-87.

BORRAS, J. R., FIG, D., SUAREZ, S. M. (2011): The politics of agrofuels and mega-land and water deals: insights from the ProCana case, Mozambique. Review of African Political Economy, 38(128): 215-234. 
BRIDGE, G., BOUZAROVSKI, S., BRADSHAW, M. EYRE, N. (2013): Geographies of energy transition: Space, place and the low-carbon economy. Energy Policy, 53: 331-340.

BURDGE, R. J., CHAMLEY, S., DOWNS, M., FINSTERBUSCH, K., FREUDENBURG, B., FRICKE, P., THOMPSON, J. G. (2003): Principles and guidelines for social impact assessment in the USA. Impact Assessment and Project Appraisal, 21(3): 231-250.

CAMERON, J. (2014): Politics of Hope: Rethinking Geographic Scale, "Impact" Scale, and Markets. Antipode, 46(1): 53-71.

CARROSIO, G. (2013): Energy production from biogas in the Italian countryside: policies and organizational models. Energy Policy, 63: 3-9.

COCKERILL, S., MARTIN, C. (2008): Are biofuels sustainable? The EU perspective. Biotechnology for Biofuels, 1(9): 1-6.

COLBRAN, N. (2011): Indigenous peoples in Indonesia: At risk of disappearing as distinct peoples in the rush for biofuel? International Journal on Minority and Group Rights, 18(1): 63-92.

COTULA, L. (2012): The international political economy of the global land rush: a critical appraisal of trends, scale, geography and drivers. The Journal of Peasant Studies, 39(3-4): 649-680.

DALLA MARTA, A., NATALI, F., MANCINI, M., FERRISE, R., BINDI, M., ORLANDINI, S. (2011): Energy and Water Use Related to the Cultivation of Energy Crops: a Case Study in the Tuscany Region. Ecology and Society, 16(2): 2.

DAUVERGNE, P., NEVILLE, K. J. (2010): Forests, food, and fuel in the tropics: The uneven social and ecological consequences of the emerging political economy of biofuels. Journal of Peasant Studies, 37(4): 631-660.

DE CARVALHO, S. P., MARIN, J. O. B. (2011): Agricultura familiar e agroindústria canavieira: impasses sociais. Revista de Economia e Sociologia Rural, 49(3): 681-708.

DUVAIL, S., MÉDARD, C., HAMERLYNCK, O., NYINGI, D. W. (2012): Land and water grabbing in an East African coastal wetland: The case of the Tana delta. Water Alternatives, 5(2): 322-343.

EUROBSERVER (2016): Biofuels barometer 2016 [online]. Available at: www.eurobserv-er.org/biofuelsbarometer-2016

FAAIJ, A. (2011): Developments in international bioenergy markets and trade. Biomass and Bioenergy, 32(8): 657-659.

FERNANDES, B. M., WELCH, C. A., GONÇALVES, E. C. (2010): Agrofuel policies in Brazil: Paradigmatic and territorial disputes. Journal of Peasant Studies, 37(4): 793-819.

FERREIRA-LEITAO, V., FORTES GOTTSCHALK, L. M., FERRARA, M. A., LIMA NEPOMUCENO, A., CORREA MOLINARI， H. B.， BON， E.P.S. (2010): Biomass Residues in Brazil: Availability and Potential Uses. Waste Biomass Valor, 1(1): 65-76.

FRANTÁL, B., PROUSEK, A. (2016): It's not right, but we do it. Exploring why and how Czech farmers become renewable energy producers. Biomass and Bioenergy, 87: 26-34.
GAMBORG, C., MILLAR, K., SHORTALL, O., SANDØE, P. (2012): Bioenergy and Land Use: Framing the Ethical Debate. Journal of Agricultural \& Environmental Ethics, 25: 909-925.

GAO, Y., SKUTSCH M., DRIGO R., PACHECO, P., MASERA, O. (2011): Assessing deforestation from biofuels: Methodological challenges. Applied Geography, 31(2): 508-518.

GERMAN, L., SCHONEVELD, G., SKUTCH, M., ANDRIANI, R., OBIDZINSKI, K., PACHECO, P. (2010): The local social and environmental impacts of biofuel feedstock expansion. A synthesis of case studies from Asia, Africa and Latin America. CIFOR infobrief, 34.

GOLTSEV, V., ILAVSKÝ, J., GERASIMOV, Y., KARJALAINEN, T. (2010): Potential for biofuel development in Tihvin and Boksitogorsk districts of the Leningrad region - The analysis of energy wood supply systems and costs. Forest Policy and Economics, 12(4): 308-316.

GRANNEC, M. L., LOUSSOUARN, A., LEVASSEUR, P. (2016): Perception sociale locale de projets de méthanisation agricole: vision croisée de différents acteurs du territoire. Journées Recherches Porcine, 48: 189-190.

GUPTA, R. B., DEMIRBAS, A. (2010): Gasoline, diesel, and ethanol biofuels from grasses and plants. Cambridge, Cambridge University Press.

JUNGINGER, M., BOLKESJØ, T., BRADLEY, D., DOLZAN, D., FAAIJ, A., HEINIMO, J., HEKTOR, B., LEISTAD, O., LING, E., PERRY, M., PIACENTE, E., ROSILLOCALLE, F., RYCKMANS, Y., SCHOUWENBERG, P., SOLBERG, B., TRØMBORG, E., DA SILVA WALTER, A., DE WIT, M. (2008): Developments in international bioenergy trade. Biomass and bioenergy, 32: 717-729.

JENSEN, M., ANDERSEN, A. H. (2013): Biofuels: A contested response to climate change. Sustainability: Science, Practice, and Policy, 9(1): 42-56.

HAZLEWOOD, J.A. (2012): $\mathrm{CO}_{2}$ lonialism and the "Unintended Consequences" of Commoditizing Climate Change: Geographies of Hope Amid a Sea of Oil Palms in the Northwest Ecuadorian Pacific Region. Journal of Sustainable Forestry, 31(1-2): 120-153.

HULTMAN, N. E., SULLE, E. B., RAMIG, C. W., SYKORABODIE, S. (2012): Biofuels Investments in Tanzania: Policy Options for Sustainable Business Models. Journal of Environment and Development, 21(3): 339-361.

HUTTUNEN, S. (2011): Embeddedness in local farm-scale bioenergy production. Ager (11): 107-127.

KALT, G., KRANZL, L. (2012): An assessment of international trade related to bioenergy use in AustriaMethodological aspects, recent developments and the relevance of indirect trade. Energy Policy, 46: 537-549.

KORTSCH, T., HILDEBRAND, J., SCHWEIZER-RIES, P. (2015): Acceptance of biomass plants-Results of a longitudinal study in the bioenergy-region Altmark. Renewable energy, 83. 690-697.

LAMERS, P., HAMELINCK, C., JUNGINGER, M., FAAIJ, A. (2011): International bioenergy trade - A review of past developments in the liquid biofuel market. Renewable and Sustainable Energy Reviews, 15(6): 2655-2676. 
LEVIDOW, L., PAUL, H. (2010): Global agrofuel crops as contested sustainability, part I: Sustaining what development? Capitalism, Nature, Socialism, 21(2): 64-86.

MABEE, W. E., MIRCK, J. (2011): A regional evaluation of potential bioenergy production pathways in Eastern Ontario Canada. Annals of the Association of American Geographers, 101(4): 897-906.

MIGNON C. (2009): Biométhanisation: utilisation du digestat comme fertilisant en agriculture. Gembloux, CRA ValBiom.

MOL, A. P. J. (2010): Environmental authorities and biofuel controversies. Environmental Politics, 19(1): 61-79.

MONTEFRIO, M. J. F., SONNENFELD, D. A. (2013): GlobalLocal Tensions in Contract Farming of Biofuel Crops Involving Indigenous Communities in the Philippines. Society and Natural Resources, 26(3): 239-253.

MONTELEONE, M., COSENTINO, S. L., DE MASTRO, G., MAZZONCINI, M. (2009): Modelli produttivi agrienergetici: l'integrazione di filiera dalla scala aziendale a quella territoriale. Italian Journal of Agronomy/Rivista di Agronomia, 4(1): 125-140.

MWAKAJE, A. G. (2012): Can Tanzania realise rural development through biofuel plantations? Insights from the study in Rufiji District. Energy for Sustainable Development, 16(3): 320-327.

NAYLOR, R.A. (2007): Ripple effects of crop-based biofuels on global food security and the environment. Environment, 49(9): 30-43.

PAIANO, A., CAMAGGIO, G., LAGIOIA, G. (2011). Territorial level for biofuel production - Case study of an Italian region. Renewable and Sustainable Energy Reviews, 15(5): 2222-2231.

PASQUALETTI, M. (2000): Morality, space, and the power of wind-energy landscape landscapes. The Geographical Review, 90(3): 381-394.

PÉREZ, M. A., PEŃA, M. R., ALVAREZ, P. (2011): Agroindustria cańera y uso del agua: Análisis crítico en el contexto de la política de agrocombustibles en Colombia. Ambiente e Sociedade, 14 (2): 153-178.

PONTI, L., GUITIERREZ, A. P. (2009): Overview on biofuel form in a European perspective. Bulletin of Science, Technology \& Society, 29(6): 493-503.

PUTTILLI, M. (2009): Per un approccio geografico alla transizione energetica. Le vocazioni energetiche territoriali. Bollettino della Società Geografica Italiana, 2(3): 601-616.

PUTTILLI, M.,TECCO, N. (2012): Tra industria e territorio. La filiera del biodiesel in una prospettiva geografica, Bollettino della Società Geografica Italiana, 5(2): 353-367.

RATHMANN, R., SZKLO, A., SCHAEFFER, R. (2010): Land use competition for production of food and liquid biofuels: An analysis of the arguments in the current debate. Renewable Energy, 35(1): 14-22.

REN21 (2017): Renewables 2017 Global Status Report, Paris: REN21 Secretariat.

ROWE, R. L., STREET, N. R., TAYLOR, G. (2009): Identifying potential environmental impacts of large-scale deployment of dedicated bioenergy crops in the UK. Renewable \& Sustainable Energy Reviews, 13(1): 271-290.
RUSSI, D. (2008): An integrated assessment of a large scale biodiesel production in Italy: Killing several birds with one stone? Energy Policy, 36(3): 1169-1180.

SAWYER, D. (2008): Climate change, biofuels and ecosocial impacts in the Brazilian Amazon and Cerrado. Philosophical Transactions of the Royal Society, 363(1498): 1747-1752.

SCARLAT, N., MARTINOV, M., DALLEMAND, J.-F. (2010): Assessment of the availability of agricultural crop residues in the European Union: Potential and limitations for bioenergy use. Waste Management, 30: 1889-1897.

SCHMITZ, S., VANDERHEYDEN, V., VANDEN BROUCKE, S., LOOPMANS, M. (2012): The Shaping of Social attitudes toward Energy-Parks in the Belgian Countryside. Horizons in Geography, 81(1): 83-93.

SCHUMACHER, K., SCHULTMANN, F. (2017): Local Acceptance of Biogas Plants: A Comparative Study in the Trinational Upper Rhine Region. Waste and Biomass Valorization, 8: 2393-2412.

SCHWEIZER-RIES, P. (2008): Energy sustainable communities: Environmental psychological investigations. Energy Policy, 36(11): 4126-4135.

SECCHI, S., KURKAKOVA, L., GASSMAN, P. W., HART, C. (2011): Land use change in a biofuel hotspot: The case of Iowa, USA. Biomass and Bioenergy, 35(6): 2391-2400.

SOLAND, M., STEIMER, N., WALTER, G. (2013): Local acceptance of existing biogas plants in Switzerland. Energy Policy, 61: 802-810.

SULLIVAN, T. P., SULLIVAN, D. S., LINDGREN P. M. F., RANSOME D. B., BULL, J. G., RISTEA, C. (2011): Bioenergy or biodiversity? Woody debris structures and maintenance of red-backed voles on clear cuts. Biomass and Bioenergy, 35(10): 4390-4398.

TATEDA,M., YAMASHITA, C., KIM,Y.,ATHAPATTU,B. C. L. (2011): Preparation for Establishing Environmentally and Socially Friendly Business in the Biomass Town of Imizu City, Toyama, Japan: A Case Study of the Waste Vegetable Oil-Recycling Business. Environmental Practice, 13(2): 143-154.

TRICASE, C., LOMBARDI, M. (2009): State of the art and prospects of Italian biogas production from animal sewage: technical-economic considerations. Renewable Energy, 34(3): 477-485.

TRITZ, Y. (2012): Le Système énergétique agri-territorial: les bioénergies comme outil de développement local. Géographie, économie, société, 14(1): 31-52.

TSAO, C. C., CAMPBELL, J.E., MENA-CARRASCO M., SPAK S. N., CARMICHAEL, G. R., CHEN, Y. (2012): Increased estimates of air-pollution emissions from Brazilian sugar-cane ethanol. Nature Climate Change, 2(1): 53-57.

VAN DER HORST, D., VERMEYLEN, S. (2011): Spatial scale and social impacts of biofuel production. Biomass and bioenergy, 35(6): 2435-2443.

VAN ROMPAEY, A., SCHMITZ, S., KESTELOOT, C., PEETERS, K., MOENS, B., VAN HEMELRIJCK, H., VANDERHEYDEN, V., LOOPMANS M., VANDEN BROUCKE, S. (2011): Landscape Capacity and Social Attitudes towards Wind Energy Projects in Belgium. Brussels, Belgium Federal Science Policy. 
VAN TROYE, P. (2016): ENGIE in light of the energy revolution, 22 Sept 2016, University of Liege.

VERMEULEN, S., COTULA, L. (2010): Over the heads of local people: consultation, consent, and recompense in large-scale land deals for biofuels projects in Africa. The Journal of Peasant Studies, 37(4): 899-916.

VOYTENKO, Y., PECK, P. (2012): Organisational frameworks for straw-based energy systems in Sweden and Denmark. Biomass and Bioenergy, 38(1): 34-48.

WALKER, G., CASS, N. (2007). Carbon reduction, 'the public' and renewable energy: engaging with socio-technical configurations. Area, 39(4): 458-469.

WILLIAMS, T. O., GYAMPOH, B., KIZITO, F., NAMARA, R. (2012): Water implications of large-scale land acquisitions in Ghana. Water Alternatives, 5(2): 243-265.
WOLSINK, M. (2007): Wind power implementation: the nature of public attitudes: Equity and fairness instead of 'backyard' motives. Renewable and sustainable energy reviews, 11(6): 1188-1207.

YAN, L.Z. (2008): Potential yield of bioethanol from energy crops and their regional distribution in China. Transactions of the Chinese Society of Agricultural Engineering, 24 (5): 213-216.

ZELLER, M., GRASS, M. (2008): Agrofuel boom or doom? Opportunities and constraints for agrofuels in developing countries. Quarterly Journal of International Agriculture, 47(4): 285-305.

ZOLIN, M. B. (2011): Diversification of Household Income in Rural Areas: Opportunities and Risks of Biomass Energy. The Open Geography Journal, 4(1): 16-28.

Please cite this article as:

CIERVO, M., SCHMITZ, S. (2017): Sustainable biofuel: A question of scale and aims. Moravian Geographical Reports, 25(4): 220-233. Doi: 10.1515/mgr-2017-0019. 